\title{
Prognostic value of preoperative body mass index for diabetic patients with non-metastasis gastric cancer: a single center experience
}

\author{
Zaisheng Ye ${ }^{1 \dagger}$, Shenghong Wei ${ }^{1 \dagger}$, Yi Zeng ${ }^{1 \dagger}$, Yi Wang ${ }^{1 \dagger}$, Zhitao Lin' ${ }^{1}$, Shu Chen ${ }^{1}$, Yunqing Xie ${ }^{2}$, \\ Qiuhong Zheng ${ }^{2}$ and Luchuan Chen ${ }^{1 *}$ (1)
}

\begin{abstract}
Aim: This study was designed to investigate the prognostic effect of preoperative body mass index (BMI) for Type 2 diabetes mellitus (T2DM) patients with non-metastasis gastric cancer (GC) who underwent $\mathrm{D}_{2}$ gastrectomy.

Methods: T2DM patients with $\mathrm{pT}_{1-4 b} \mathrm{~N}_{0-3 \mathrm{~b}} \mathrm{M}_{0} \mathrm{GC}$ were retrospectively collected in Department of Gastrointestinal Surgical Oncology, Fujian Cancer Hospital \& Fujian Medical University Cancer Hospital from January, 2000 to December, 2010. These patients underwent $\mathrm{D}_{2}$ radical resection of the stomach combined with regional lymphadenectomy. Chi-square test was used to analyze unordered categorical variables and ranked data, followed by Kaplan-Meier analysis as well as Cox regression models to detect risk factors for survival outcomes. In addition, the cut-off point was determined by the X-tile program. All analyses were carried out using survival package of R and SPSS Software.

Results: A total of 302 T2DM patients with $\mathrm{pT}_{1-4 \mathrm{~b}} \mathrm{~N}_{0-3 \mathrm{~b}} \mathrm{M}_{0} \mathrm{GC}$ were collected and analyzed. The cut-off points of BMl, identified by the X-tile program, was $19 \mathrm{~kg} / \mathrm{m}^{2}$. Patients with low BMI $\left(<19 \mathrm{~kg} / \mathrm{m}^{2}\right)$ had a higher percentage of advanced $T$ stage $\left(T_{4 a}\right.$ and $T_{4 b}$ ), more advanced TNM stage (stage IIIA, IIIB and IIIC), and more elevated level of serum carcinoembryonic antigen (CEA), compared to those with high BMI $\left(>19 \mathrm{~kg} / \mathrm{m}^{2}\right)($ all $P<0.05)$. In the low BMI subgroup, the 5-year overall survival rate was $39.02 \%$, which was as high as $58.11 \%$ in the high BMI subgroup $(P<0.05)$. In the multivariate Cox regression model revealed that $\mathrm{II}_{C}$ stage $(\mathrm{OR}=3.101), \mathrm{N}_{3 \mathrm{~b}}$ stage $(\mathrm{OR}=3.113)$ were the most important prognostic indicators, followed by pretreatment $\mathrm{BMI}(\mathrm{OR}=2.136)$.
\end{abstract}

Conclusion: Low preoperative BMI $\left(<19 \mathrm{~kg} / \mathrm{m}^{2}\right)$ was a poor prognostic marker for T2DM patients with $\mathrm{pT}_{1-4 \mathrm{~b}} \mathrm{~N}_{0-3 \mathrm{~b}} \mathrm{M}_{0}$ GC.

Keywords: BMI, Type 2 diabetes mellitus, Gastric cancer, X-tile, Survival rate

*Correspondence: luchuanchen@sina.cn

'Zaisheng Ye, Shenghong Wei, Yi Zeng and Yi Wang contributed equally to the work

${ }^{1}$ Department of Gastrointestinal Surgical Oncology, Fujian Cancer Hospital, and Fujian Medical University Cancer Hospital, No. 420 Fu-ma Road, Jin-An District, Fuzhou 350014, China

Full list of author information is available at the end of the article

\section{Introduction}

Gastric cancer (GC) ranks the second in all cases of cancer-related mortality, accounting for approximately 1 million GC-related deaths per year [1]. $\mathrm{D}_{2}$ radical resection of the stomach combined with regional lymphadenectomy has been verified to be the single radical option [2-6]. Although there has been great advance in diagnosis as well as treatment of GC, little progress has been achieved in long-term prognosis. Hence, it is particularly 
necessary to find a novel prognostic marker, which is noninvasive and accessible before treatment.

Type 2 diabetes mellitus $\left(\mathrm{T}_{2} \mathrm{DM}\right)$ has gradually become a growing global public health burden [7]. The prevalence of $\mathrm{T}_{2} \mathrm{DM}$ is up to $8.3 \%$ worldwide [8] according to the International Diabetes Federation, which varies in different regions and countries. It is estimated that 552 million people will develop diabetes by 2030 globally [8]. $\mathrm{T}_{2} \mathrm{DM}$ may predispose patients to premature illness and death due to the relevant risks of cardiovascular diseases [9]. The prevalence of $\mathrm{T}_{2} \mathrm{DM}$ has enhanced substantially in recent years, and the presence of $\mathrm{T}_{2} \mathrm{DM}$ has been confirmed to be related with increased risks of multiple malignancies [10]. Moreover, and the relationship between diabetes mellitus (DM) and risks of developing cancers has been examined in numerous meta-analyses.

Obesity is an emerging risk factor for several cancers worldwide, and the relationship between obesity and cancers has been well investigated in various types of malignancies [11-14]. $\mathrm{T}_{2} \mathrm{DM}$ is a multifactorial and chronic group of metabolic disorders characterized by hyperglycemia $[7,15]$, which is a result of obesity to some extent. In consideration of the relationship between obesity and long-term post-operative outcome in GC patients, several studies have revealed that obesity/overweight may correlate with the long-term outcome.

Body mass index (BMI) is the most commonly used index of body mass [16]. Some authors have suggested a relationship between increased BMI and esophageal and gastric cardia adenocarcinoma [17-19]. Conversely, some studies have demonstrated that high BMI was associated with a good prognosis of GC patients [20, 21]. According to the World Health Organization (WHO) classification system, BMI is generally categorized into the following four grades [22]: underweight $\left(<18.5 \mathrm{~kg} / \mathrm{m}^{2}\right)$, normal weight (18.5-24.9 kg/m²), overweight $\left(25.0-29.9 \mathrm{~kg} / \mathrm{m}^{2}\right)$, and obese $\left(\geq 30.0 \mathrm{~kg} / \mathrm{m}^{2}\right)$. However, it hardly matches the true circumstance for the GC patients with $\mathrm{T}_{2} \mathrm{DM}$. The role of preoperative BMI on the survival of $\mathrm{T}_{2} \mathrm{DM}$ patients with GC survival remains unclear. Hence, the retrospective study was designed to investigate the effect of preoperative BMI on the survival outcome in $\mathrm{T}_{2} \mathrm{DM}$ patients with non-metastatic $\mathrm{GC}$ after $\mathrm{D}_{2}$ gastrectomy.

\section{Methods}

\section{Patients and clinicopathological characteristics}

The clinical data of 302 patients with non metastatic diabetes and GC who underwent $\mathrm{D}_{2}$ lymph node dissection from January 2000 to December 2012 at the Department of Gastrointestinal Surgery of, Fujian Cancer Hospital \& Fujian Medical University Cancer Hospital were retrospectively analyzed similar to the cohort of previous studies [23].
The inclusion criteria were as follows: (1) pathological diagnosis was adenocarcinoma; (2) $\mathrm{D}_{2}$ lymphadenectomy (according to the guidelines of the 2010 Japanese Classification of Gastric Cancer and Gastric Cancer Treatment Guidelines edited by the Japanese Gastric Cancer Association [24]; (3) I-III stage (AJCC TNM 7th edition) [25]; (4) preprandial glucose $>7.1 \mathrm{mmo} / \mathrm{L}$.

The exclusion criteria were as follows: $(1)>80$ years of age; (2) history of gastrectomy; (3) previous or combined with other cancer; (4) IV stage (AJCC TNM 7th edition; (5) history of neoadjuvant therapy; (6) non R0 resection; (7) mortality within non tumor causes [23].

The patients were conducted followed-up interviews over the telephone. The information regarding the survival status at the last follow-up was collected similar to the cohort of previous studies. The last follow-up was 1 January 2017 [23].

\section{Statistical analysis}

Chi-square test was used for qualitative data. The survival analysis was performed by the Kaplan-Meier and Cox regression methods. The X-tile program was used to determine the optimal cutoff [26]. All analyses were performed with survival package of $\mathrm{R}$ (Version 3.2.1) and SPSS (Version 22.0). Prism 5 for Windows (Version 5.01, GraphPad Software) was used to draft the figure of Kaplan-Meier curve. Values of $\mathrm{P}<0.05$ were considered significant.

\section{Results \\ Identification of BMI cut-off points}

$\mathrm{X}$-tail plots, constructed in, illustrated that the optimal cut-off point of BMI was $19 \mathrm{~kg} / \mathrm{m}^{2}$ using minimum $P$ value from log-rank $\div 2$ test, with the strongest discriminatory capacity (Fig. 1).

\section{Clinicopathologic characteristics of patients}

A total of $302 \mathrm{~T}_{2} \mathrm{DM}$ patients with $\mathrm{pT}_{1-4 \mathrm{~b}} \mathrm{~N}_{0-3 \mathrm{~b}} \mathrm{M}_{0} \mathrm{GC}$, underwent $D_{2}$ radical resection, were collected for analysis with 132 deaths in a median follow-up of 87.6 months (range 63 to 114 months). A detailed description of the associations between BMI level and clinic-pathological characteristics were presented in Table 1. As anticipated, patients with low BMI $\left(<19 \mathrm{~kg} / \mathrm{m}^{2}\right)$ have high percentage of female, advanced $\mathrm{T}_{4}$ category $\left(\mathrm{T}_{4 \mathrm{a}}\right.$ and $\left.\mathrm{T}_{4 \mathrm{~b}}\right)$, advanced TNM category (stage $\mathrm{III}_{\mathrm{A}}, \mathrm{III}_{\mathrm{B}}$ and $\mathrm{III}_{\mathrm{C}}$ ), and level of serum CEA (all $P<0.05$ ). In the low BMI subgroup, the percentage of $\mathrm{T}_{4}$ category $(79.3 \%$ vs $56.6 \%, \mathrm{P}=0.002)$ and stage ${ }_{\text {III }}(79.3 \%$ vs $56.1 \%, P=0.002)$ was significantly higher in the low BMI subgroup than in the high BMI subgroup. 

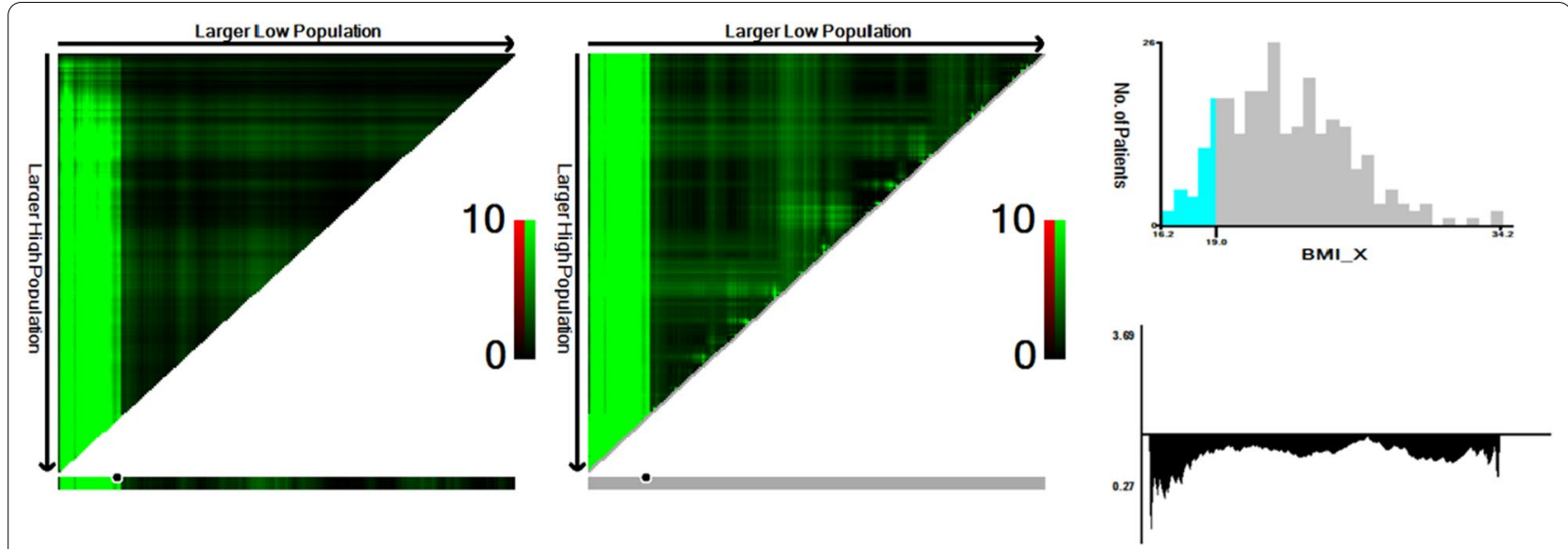

Fig. 1 X-tile analysis of survival data. X-tile analysis was done on gastric cancer patients with $\mathrm{T}_{2} \mathrm{DM}$. The optimal cut-point highlighted in the left panels and a Kaplan-Meier plot (right panels). $P$ values were determined by using the cut-point defined in the training set and applying it to the validation set. Figures show BMI count divided the optimal cut-point $\left(19 \mathrm{~kg} / \mathrm{m}^{2}, \mathrm{X}^{2}=57.308, P<0.001\right)$

Table 1 Demographics and clinicopathologic characteristics of patients with gastric cancer

\begin{tabular}{|c|c|c|c|c|c|}
\hline & $\begin{array}{l}\mathrm{BMI}<19 \mathrm{~kg} / \mathrm{r} \\
(\mathrm{n}=29)\end{array}$ & & $\begin{array}{l}\mathrm{BMI} \geq 19 \mathrm{~kg} / \mathrm{m} \\
(\mathrm{n}=273)\end{array}$ & & $P$-value \\
\hline \multicolumn{6}{|c|}{ H. pylori infection } \\
\hline Y & 2 & $6.9 \%$ & 17 & $7.2 \%$ & 0.975 \\
\hline$N$ & 27 & $93.1 \%$ & 220 & $92.8 \%$ & \\
\hline Age & $\begin{array}{l}56.69 \pm 13.1 \\
57(30-79)\end{array}$ & & $\begin{array}{l}58.81 \pm 11.27 \\
59(23-82)\end{array}$ & & \\
\hline \multicolumn{6}{|l|}{ Sex } \\
\hline M & 16 & $55.2 \%$ & 180 & $75.9 \%$ & 0.016 \\
\hline $\mathrm{F}$ & 13 & $44.8 \%$ & 57 & $24.1 \%$ & \\
\hline CEA level & $14.32 \pm 4.53$ & & $11.58 \pm 3.38$ & & 0.004 \\
\hline \multicolumn{6}{|c|}{ T category } \\
\hline $1 \mathrm{a}$ & - & - & 22 & $9.3 \%$ & 0.003 \\
\hline $1 b$ & - & - & 22 & $9.3 \%$ & $0.002^{\#}$ \\
\hline 2 & 3 & $10.3 \%$ & 34 & $14.3 \%$ & \\
\hline 3 & 3 & $10.3 \%$ & 25 & $10.5 \%$ & \\
\hline $4 a$ & 18 & $62.1 \%$ & 127 & $53.6 \%$ & \\
\hline $4 b$ & 5 & $17.2 \%$ & 7 & $3 \%$ & \\
\hline \multicolumn{6}{|c|}{ N category } \\
\hline 0 & 4 & $13.8 \%$ & 79 & $33.3 \%$ & 0.301 \\
\hline 1 & 7 & $24.1 \%$ & 41 & $17.3 \%$ & $0.082^{\$}$ \\
\hline 2 & 7 & $24.1 \%$ & 41 & $17.3 \%$ & \\
\hline 3a & 6 & $20.7 \%$ & 45 & $19 \%$ & \\
\hline $3 b$ & 5 & $17.2 \%$ & 31 & $13.1 \%$ & \\
\hline \multicolumn{6}{|c|}{ TNM category } \\
\hline IA & 0 & & 34 & $14.3 \%$ & 0.213 \\
\hline $\mathrm{IB}$ & 1 & $3.4 \%$ & 23 & $9.7 \%$ & $0.002^{\&}$ \\
\hline$\| \mathrm{A}$ & 3 & $10.3 \%$ & 20 & $8.4 \%$ & \\
\hline$\| B$ & 2 & $6.9 \%$ & 27 & $11.4 \%$ & \\
\hline$\| \mathrm{A}$ & 6 & $20.7 \%$ & 31 & $13.1 \%$ & \\
\hline$\| I \mathrm{~B}$ & 6 & $20.7 \%$ & 37 & $15.6 \%$ & \\
\hline$\| I I C$ & 11 & $37.9 \%$ & 65 & $27.4 \%$ & \\
\hline
\end{tabular}

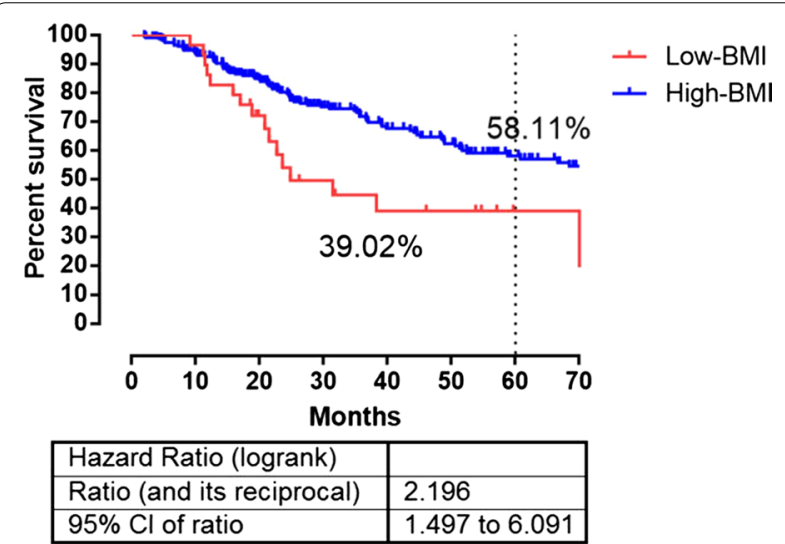

Fig. 2 Survival analysis of gastric cancer patients with $T_{2} D M$ undergoing curative intent surgery. The $\mathrm{P}$ values for the survival comparison was determined by the log-rank test

\section{Survival analysis}

The 5-year OS of $\mathrm{T}_{2} \mathrm{DM}$ GC patients whose BMI less than $19 \mathrm{~kg} / \mathrm{m}^{2}$ and more than $19 \mathrm{~kg} / \mathrm{m}^{2}$ subgroups were $39.02 \%$ and $58.11 \%$, respectively (Fig. 2). At the same time, the risk level of BMI was built using the linear combination of BMI with the estimated regression coefficients derived from the above Cox regression analysis as the weight to calculate the death risk score for each patient. Distribution of death and the survival status of stage $\mathrm{I}_{\mathrm{A}}-\mathrm{III}_{\mathrm{C}} \mathrm{GC}$ were shown in Fig. 3. The plot of HRs for BMI sharply decreased as the level of BMI increased. 

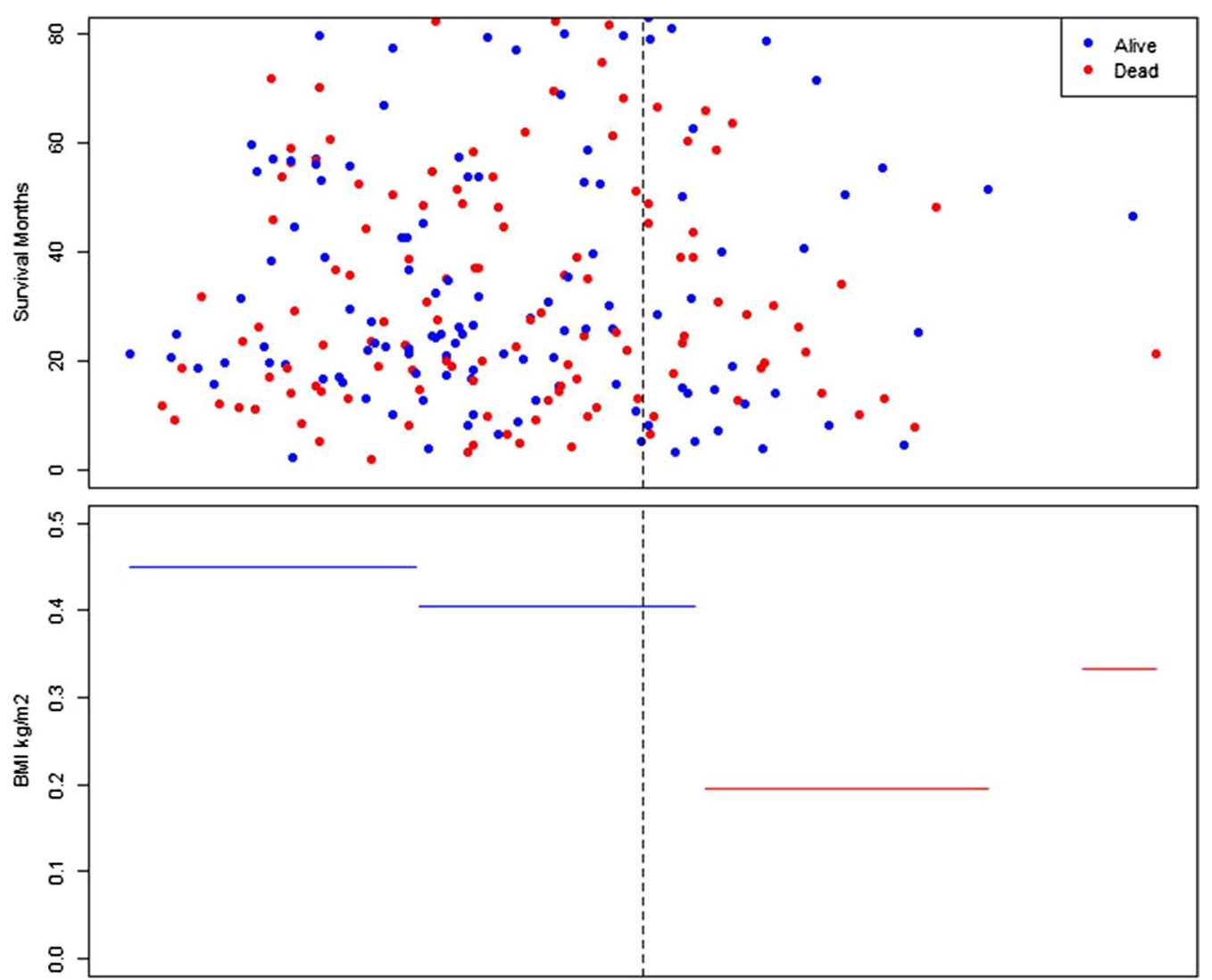

Fig. 3 The risk score of BMI. The plot of HRs for BMI sharply increased as the number of BMI decreased

\section{Independent prognostic factors in the training cohort}

Variables considered significant in the multivariate analysis were entered in the Cox multivariate analysis. A total of six variables, including $H$. pylori infection $(\mathrm{OR}=1.439)$, sex $(\mathrm{OR}=0.943)$ have no statistical power (all $P>0.05)$. However, pretreatment BMI $(\mathrm{OR}=2.136)$, $\mathrm{III}_{\mathrm{B}}$ category $(\mathrm{OR}=1.845), \mathrm{III}_{\mathrm{C}}$ category $(\mathrm{OR}=3.101)$, $\mathrm{T}_{4 \mathrm{a}}$ category $(\mathrm{OR}=1.617), \mathrm{T}_{4 \mathrm{~b}}$ category $(\mathrm{OR}=1.8), \mathrm{N}_{1 \mathrm{c}}$ category $(\mathrm{OR}=1.701), \mathrm{N}_{2}$ category $(\mathrm{OR}=1.812), \mathrm{N}_{3 \mathrm{a}}$ category $(\mathrm{OR}=2.145)$, and $\mathrm{N}_{3 \mathrm{~b}}$ category $(\mathrm{OR}=3.113)$, respectively (all $\mathrm{P}<0.05$ ) were proved independent in the multivariate Cox regression model (Table 2, Fig. 4).

\section{Discussion}

To the best of our knowledge, our work is the first one to systematically assess the clinical significance of BMI level in $\mathrm{T}_{2} \mathrm{DM}$ patients with non-metastatic GC. In spite of unclear underlying mechanisms, our study reveals that the pretreatment BMI is a significant indicator in predicting cancer-specific survival (CSS) in GC patients with
$\mathrm{T}_{2} \mathrm{DM}$. In the Cox multivariate analysis, pretreatment BMI under $19 \mathrm{~kg} / \mathrm{m}^{2}$ was found to be an independent prognostic factor $(\mathrm{OR}=2.136)$.

The important aspect in the intricate relation between the effect of BMI and GC is still unknown. Many investigation have been made on this relation, which harbor diverse results in terms of survival, pathological findings and surgical procedures [21, 27, 28]. Recent studies have reported a significantly decreased overall survival (OS) in underweight patients, defined as BMI under $18.5 \mathrm{~kg} / \mathrm{m}^{2}$, who previously underwent gastrectomy due to GC [29], indicating a close correlation between low BMI and poor prognosis in GC patients. Consistently, our study found that the pretreatment BMI is a significant predictor of CSS in GC patients with $\mathrm{T}_{2} \mathrm{DM}$. It was further confirmed that a preoperative $\mathrm{BMI}<19 \mathrm{~kg} / \mathrm{m}^{2}$ was a predictor of poor prognosis.

Lymph node involvement has been verified as the most independently essential factor for survival of GC [30-34], whose accurate evaluation largely depends on the sufficiency of lymphadenectomy [35]. In our data, 
Table 2 Cox proportional hazards multivariate regression analysis results

\begin{tabular}{|c|c|c|c|c|c|c|c|}
\hline & \multirow[t]{2}{*}{ B } & \multirow[t]{2}{*}{ SE } & \multirow[t]{2}{*}{ Wald } & \multirow[t]{2}{*}{ Sig } & \multirow[t]{2}{*}{$\operatorname{Exp}(B)$} & \multicolumn{2}{|c|}{$\begin{array}{l}95.0 \% \mathrm{Cl} \text { used for } \\
\operatorname{Exp}(\mathrm{B})\end{array}$} \\
\hline & & & & & & Low & Upper \\
\hline H. pylori infection & 0.364 & 0.368 & 0.977 & 0.323 & 1.439 & 0.699 & 2.959 \\
\hline Sex & -0.059 & 0.254 & 0.053 & 0.818 & 0.943 & 0.573 & 1.552 \\
\hline BMI & 0.036 & 0.005 & 43.388 & 0.000 & 2.136 & 1.525 & 3.147 \\
\hline \multicolumn{8}{|l|}{ TNM category } \\
\hline $\mid A$ & & & & & 1 (reference) & & \\
\hline IB & -7.243 & 36.242 & 0.040 & 0.842 & 1.153 & 0.514 & 2.584 \\
\hline$\| \mathrm{A}$ & -7.871 & 36.272 & 0.047 & 0.828 & 1.211 & 0.704 & 2.130 \\
\hline$\| \mathrm{B}$ & -9.443 & 36.313 & 0.068 & 0.795 & 1.331 & 0.654 & 2.411 \\
\hline$\| I A$ & -10.091 & 36.359 & 0.077 & 0.781 & 1.411 & 0.704 & 2.830 \\
\hline$\| I \mid B$ & -10.396 & 36.399 & 0.082 & 0.000 & 1.845 & 1.410 & 2.312 \\
\hline IIIC & -10.747 & 36.446 & 0.087 & 0.000 & 3.101 & 2.33 & 4.312 \\
\hline \multicolumn{8}{|l|}{ T category } \\
\hline $1 a$ & & & & & 1 (reference) & & \\
\hline $1 b$ & 5.579 & 17.095 & 0.107 & 0.744 & 1.153 & 0.514 & 2.584 \\
\hline 2 & 12.454 & 40.017 & 0.097 & 0.756 & 1.411 & 0.704 & 2.830 \\
\hline 3 & 14.452 & 40.041 & 0.130 & 0.718 & 1.230 & 0.654 & 2.311 \\
\hline $4 a$ & 14.850 & 40.063 & 0.137 & 0.012 & 1.617 & 1.308 & 3.130 \\
\hline $4 b$ & 15.474 & 40.076 & 0.149 & 0.008 & 1.908 & 1.318 & 4.000 \\
\hline \multicolumn{8}{|l|}{ N category } \\
\hline 0 & & & & & 1 (reference) & & \\
\hline 1 & 2.678 & 1.090 & 6.036 & 0.002 & 1.701 & 1.216 & 2.406 \\
\hline 2 & 3.187 & 1.502 & 4.503 & 0.000 & 1.812 & 1.322 & 2.517 \\
\hline $3 a$ & 3.918 & 1.919 & 4.167 & 0.000 & 2.145 & 1.510 & 3.034 \\
\hline $3 b$ & 3.994 & 1.882 & 4.502 & 0.000 & 3.113 & 2.133 & 4.539 \\
\hline
\end{tabular}

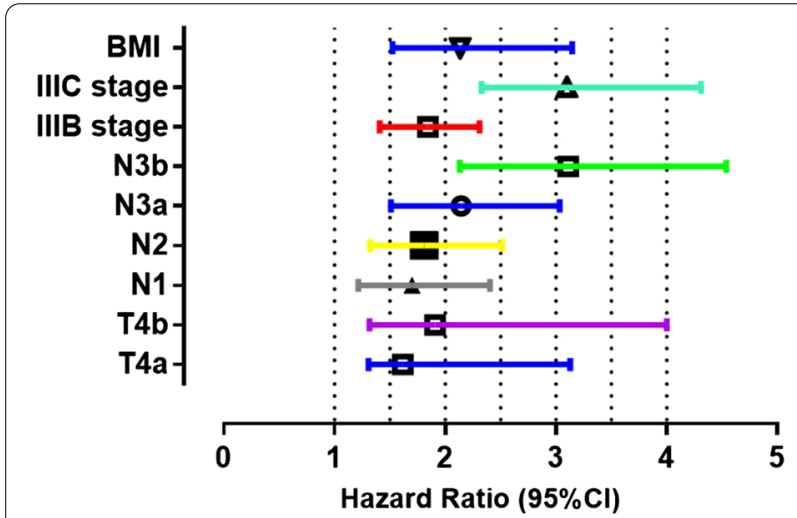

Fig. 4 Cox multivariate analyses of prognostic factors for the overall survival of non-metastatic gastric cancer patients with $\mathrm{T}_{2} \mathrm{DM}$ after $\mathrm{D}_{2}$ lymphadenectomy

$\mathrm{N}_{3 \mathrm{~b}}$ category $(\mathrm{OR}=3.113)$ was the most vital indicator, followed by $\mathrm{N}_{3 \mathrm{a}}$ category $(\mathrm{OR}=2.145), \mathrm{N}_{2}$ category $(\mathrm{OR}=1.812)$, and $\mathrm{N}_{1}$ category $(\mathrm{OR}=1.701)$. Curative surgery of GC is rather tough in case of $\mathrm{T}_{4}$ category, which includes tumor extension into serosa $\left(\mathrm{T}_{4 \mathrm{a}}\right)$ as well as surrounding organs and tissues $\left(\mathrm{T}_{4 \mathrm{~b}}\right)$, which bears an unsatisfactory prognosis [36-38]. The 5-year survival rate of patients with $\mathrm{T}_{4 \mathrm{a}} \mathrm{GC}$ has been reported to be rather low, $20 \%$ of whom pass away due to recurrence despite radical surgery of primary lesions. In the cohort, the percentage of $\mathrm{T}_{4}$ was up to $79.3 \%$ in patients with $\mathrm{BMI}<19 \mathrm{~kg} / \mathrm{m}^{2}$, and the corresponding data was $56.6 \%$ in the subgroup of $\mathrm{BMI} \geq 19 \mathrm{~kg} / \mathrm{m}^{2}(\mathrm{P}=0.002)$. In the cox multivariate analysis, $\mathrm{T}_{4 \mathrm{a}}$ category $(\mathrm{OR}=1.617), \mathrm{T}_{4 \mathrm{~b}}$ category $(\mathrm{OR}=1.908)$ were found to be independent risk factors. Pathologic TNM category is a helpful tool to predict prognosis in GC patients, nonetheless, a combination of preoperative BMI level can enhance predictive accuracy $[39,40]$. In line with studies in other types of cancers, our findings demonstrated that low preoperative BMI $\left(<19 \mathrm{~kg} / \mathrm{m}^{2}\right)$ was a hazard factor for poor survival in patients with GC.

The phenomenon that obesity increase the risks of obesity-associated complications but decrease the mortality of patients which have critically illness is called "obesity paradox". The underlying mechanism of obesity paradox still unclear but several explanations have been 
proposed. Some researchers doubt the protective effect of obesity in patients because they think that selection bias of patients exists. Subjective viewpoint of observational study and meta-analysis and the validity of BMI in patient's evaluation may also confound the results of study about obesity paradox [41]. On the other hand, some mechanism about how adipose tissue exert protective effect have been proposed. They claimed that adipose tissues may be a marker of better health status of patients and be a source of energy and lipid-soluble nutrients. Marques et al. reported that adipose tissues may modulate the immune system of patients which may help with the improved survival [42]. The result of our study is another evidence that higher BMI may help patients get better prognosis.

Our work was a retrospective single-institute study, which was the major limitation. Anyhow, our work demonstrated for the first time that pretreatment BMI was associated with the prognosis of GC patients with $\mathrm{T}_{2} \mathrm{DM}$. Specifically, a low pretreatment BMI predicted poor survival outcomes in GC patients with $\mathrm{T}_{2} \mathrm{DM}$. The application of BMI is efficient, cost-effective and easycalculated compared to other invasive procedures.

Collectively, our data showed that low preoperative BMI $\left(<19 \mathrm{~kg} / \mathrm{m}^{2}\right)$ was a prognostic factor for poor survival in patients with GC, and was useful in clinical practice and research design.

\section{Conclusion}

Low preoperative BMI $\left(<19 \mathrm{~kg} / \mathrm{m}^{2}\right)$ was a poor prognostic marker for T2DM patients with $\mathrm{pT}_{1-4 \mathrm{~b}} \mathrm{~N}_{0-3 \mathrm{~b}} \mathrm{M}_{0}$ GC.

\section{Abbreviations}

BMI: Body mass index; T2DM: Type 2 diabetes mellitus; GC: Gastric cancer; WHO: World Health Organization; TNM: Tumor-node-metastasis; NCCN: National Comprehensive Cancer Network.

\section{Acknowledgements}

We appreciate the help from Ms. Xiaoling Chen in collecting the follow-up data for this study.

\section{Authors' contributions}

ZY and SW: acquisition of data and drafting of the article; ZY, YX and QZ: participated in the data analysis; YZ, YW, SC and ZL: analysis and interpretation of the data and statistical expertise; ZY, SW and LC: conception and design of the study. All of authors reviewed the manuscript. All authors read and approved the final manuscript.

\section{Funding}

This research was sponsored by the National Clinical Key Specialty Construction Program of China and grants from the National Science Foundation Project of Fujian Science and Technology Department (No. 2017J01264 and No. 2018Y0015), Foundation for Fujian Provincial Health Technology Project (No. 2019-ZQN-16, 2019-CXB-9, 2019006) and Startup Fund for scientific research, Fujian Medical University (No. 2017Q1219, 2017Q1220). Funding was mainly used for data collection, follow-up, statistical analysis, expert communications, and native English editing.

\section{Availability of data and materials}

The datasets used and analyzed during the current study are available from the corresponding author on reasonable request.

\section{Declarations}

Ethics approval and consent to participate

This study was approved by Institutional Ethnic Committee of Fujian Medical University Cancer Hospital.Patients were not required to give informed consent to the study because the analysis used anonymous clinical data that were obtained after each patient agreed to treatment by verbal consent. Individuals can't be identified according to the data presented.

\section{Consent for publication}

Not applicable.

\section{Competing interests}

The authors declare no conflicts of interest regarding this manuscript.

\section{Author details}

'Department of Gastrointestinal Surgical Oncology, Fujian Cancer Hospital, and Fujian Medical University Cancer Hospital, No. 420 Fu-ma Road, Jin-An District, Fuzhou 350014, China. ${ }^{2}$ Department of Fujian Provincial Key Laboratory of Tumor Biotherapy, Fujian Cancer Hospital \& Fujian Medical University Cancer Hospital, Fuzhou 350014, Fujian, China.

Received: 21 December 2020 Accepted: 2 August 2021

Published online: 09 August 2021

\section{References}

1. Kamangar F, Dores GM, Anderson WF. Patterns of cancer incidence, mortality, and prevalence across five continents: defining priorities to reduce cancer disparities in different geographic regions of the world. J Clin Oncol. 2006;24(14):2137-50. https://doi.org/10.1200/JCO.2005.05.2308.

2. Han DS, Suh YS, Kong SH, Lee HJ, Choi Y, Aikou S, Sano T, Park BJ, Kim WH, Yang HK. Nomogram predicting long-term survival after d2 gastrectomy for gastric cancer. J Clin Oncol. 2012;30(31):3834-40. https://doi.org/10. 1200/JCO.2012.41.8343.

3. Chang JS, Kim KH, Yoon HI, Hyung WJ, Rha SY, Kim HS, Lee YC, Lim JS, Noh $\mathrm{SH}$, Koom WS. Locoregional relapse after gastrectomy with D2 lymphadenectomy for gastric cancer. Br J Surg. 2017;104(7):877-84. https://doi. org/10.1002/bjs.10502.

4. Mizuno A, Shinohara H, Haruta S, Tsunoda S, Kurahashi Y, Ohkura Y, Udagawa $\mathrm{H}$, Sakai Y. Lymphadenectomy along the infrapyloric artery may be dispensable when performing pylorus-preserving gastrectomy for early middle-third gastric cancer. Gastric Cancer. 2017;20(3):543-7. https://doi. org/10.1007/s10120-016-0632-2.

5. Son SY, Shin DJ, Park YS, Oo AM, Jung DH, Lee CM, Ahn SH, Park DJ, $\mathrm{Kim} \mathrm{HH}$. Spleen-preserving lymphadenectomy versus splenectomy in laparoscopic total gastrectomy for advanced gastric cancer. Surg Oncol. 2017;26(2):207-11. https://doi.org/10.1016/j.suronc.2017.04.002.

6. Woo Y, Goldner B, Ituarte P, Lee B, Melstrom L, Son T, Noh SH, Fong $Y$, Hyung WJ. Lymphadenectomy with optimum of 29 lymph nodes retrieved associated with improved survival in advanced gastric cancer: a 25,000-patient international database study. J Am Coll Surg. 2017;224(4):546-55. https://doi.org/10.1016/j.jamcollsurg.2016.12.015.

7. Xu CX, Zhu HH, Zhu YM. Diabetes and cancer: associations, mechanisms, and implications for medical practice. World J Diabetes. 2014;5(3):372-80. https://doi.org/10.4239/wjd.v5.i3.372.

8. L'Heveder R, Nolan T. International diabetes federation. Diabetes Res Clin Pract. 2013;101(3):349-51. https://doi.org/10.1016/j.diabres.2013.08.003.

9. Mazzone T. Intensive glucose lowering and cardiovascular disease prevention in diabetes: reconciling the recent clinical trial data. Circulation. 2010;122(21):2201-11. https://doi.org/10.1161/CIRCULATIONAHA.109. 913350.

10. Shi Y, Hu FB. The global implications of diabetes and cancer. Lancet. 2014;383(9933):1947-8. https://doi.org/10.1016/S0140-6736(14)60886-2. 
11. Calle EE, Rodriguez C, Walker-Thurmond K, Thun MJ. Overweight, obesity, and mortality from cancer in a prospectively studied cohort of U.S. adults. N Engl J Med. 2003;348(17):1625-38. https://doi.org/10.1056/NEJMo a021423.

12. Oh SW, Yoon YS, Shin SA. Effects of excess weight on cancer incidences depending on cancer sites and histologic findings among men: Korea National Health Insurance Corporation Study. J Clin Oncol. 2005;23(21):4742-54. https://doi.org/10.1200/JCO.2005.11.726.

13. Renehan AG, Tyson M, Egger M, Heller RF, Zwahlen M. Body-mass index and incidence of cancer: a systematic review and meta-analysis of prospective observational studies. Lancet. 2008;371(9612):569-78. https:// doi.org/10.1016/S0140-6736(08)60269-X.

14. Wang J, Yang DL, Chen ZZ, Gou BF. Associations of body mass index with cancer incidence among populations, genders, and menopausal status: a systematic review and meta-analysis. Cancer Epidemiol. 2016;42:1-8. https://doi.org/10.1016/j.canep.2016.02.010

15. Takeuchi D, Koide N, Komatsu D, Okumura M, Suzuki A, Miyagawa S. Relationships of obesity and diabetes mellitus to other primary cancers in surgically treated gastric cancer patients. Int J Surg. 2014;12(6):587-93. https://doi.org/10.1016/j.ijsu.2014.04.012.

16. Criqui MH, Klauber MR, Barrett-Connor E, Holdbrook MJ, Suarez L, Wingard DL. Adjustment for obesity in studies of cardiovascular disease. Am J Epidemiol. 1982;116(4):685-91.

17. Abnet CC, Freedman ND, Hollenbeck AR, Fraumeni JF Jr, Leitzmann M, Schatzkin A. A prospective study of BMl and risk of oesophageal and gastric adenocarcinoma. Eur J Cancer. 2008;44(3):465-71. https://doi.org/ 10.1016/j.ejca.2007.12.009.

18. Cho Y, Lee DH, Oh HS, Seo JY, Lee DH, Kim N, Jeong SH, Kim JW, Hwang $J H$, Park YS, Lee SH, Shin CM, Jo HJ, Jung HC, Yoon YB, Song IS. Higher prevalence of obesity in gastric cardia adenocarcinoma compared to gastric non-cardia adenocarcinoma. Dig Dis Sci. 2012;57(10):2687-92. https://doi.org/10.1007/s10620-012-2095-6.

19. O'Doherty MG, Freedman ND, Hollenbeck AR, Schatzkin A, Abnet CC. A prospective cohort study of obesity and risk of oesophageal and gastric adenocarcinoma in the NIH-AARP Diet and Health Study. Gut. 2012;61(9):1261-8. https://doi.org/10.1136/gutjnl-2011-300551.

20. Tokunaga M, Hiki N, Fukunaga T, Ohyama S, Yamaguchi T, Nakajima T. Better 5-year survival rate following curative gastrectomy in overweight patients. Ann Surg Oncol. 2009;16(12):3245-51. https://doi.org/10.1245/ s10434-009-0645-8.

21. Kulig J, Sierzega M, Kolodziejczyk P, Dadan J, Drews M, Fraczek M, Jeziorski A, Krawczyk M, Starzynska T, Wallner G, Polish Gastric Cancer Study G. Implications of overweight in gastric cancer: a multicenter study in a Western patient population. Eur J Surg Oncol. 2010;36(10):969-76. https://doi.org/10.1016/j.ejso.2010.07.007.

22. Luczynski W, Szypowska A, Bossowski A, Ramotowska A, Recko P, Rembinska M, Tercjak M, Blecharczyk B, Lachowska U, Suchon P, Wisniewska K, Bernatowicz P, Glowinska-Olszewska B. Overweight, obesity and metabolic syndrome in children with type 1 diabetes melllitus. Pediatr Endocrinol Diabetes Metab. 2010;16(2):83-8.

23. Xiao J, Ye ZS, Wei SH, Zeng Y, Lin ZM, Wang Y, Teng WH, Chen LC. Prognostic significance of pretreatment serum carcinoembryonic antigen levels in gastric cancer with pathological lymph node-negative: a large sample single-center retrospective study. World J Gastroenterol. 2017;23(48):8562-9. https://doi.org/10.3748/wjg.v23.i48.8562

24. Sano T. Evaluation of the gastric cancer treatment guidelines of the Japanese Gastric Cancer Association. Gan to kagaku ryoho Cancer Chemother. 2010;37(4):582-6.

25. Santiago JM, Sasako M, Osorio J. TNM-7th edition 2009 (UICC/AJCC) and Japanese Classification 2010 in Gastric Cancer. Towards simplicity and standardisation in the management of gastric cancer. Cirugia espanola. 2011;89(5):275-81. https://doi.org/10.1016/j.ciresp.2010.10.011.

26. Camp RL, Dolled-Filhart M, Rimm DL. X-tile: a new bio-informatics tool for biomarker assessment and outcome-based cut-point optimization. Clin Cancer Res. 2004;10(21):7252-9. https://doi.org/10.1158/1078-0432. CCR-04-0713.

27. Bickenbach KA, Denton B, Gonen M, Brennan MF, Coit DG, Strong VE. Impact of obesity on perioperative complications and long-term survival of patients with gastric cancer. Ann Surg Oncol. 2013;20(3):780-7. https:// doi.org/10.1245/s10434-012-2653-3.

28. Park SM, Lim MK, Shin SA, Yun YH. Impact of prediagnosis smoking, alcohol, obesity, and insulin resistance on survival in male cancer patients: National Health Insurance Corporation Study. J Clin Oncol. 2006;24(31):5017-24. https://doi.org/10.1200/JCO.2006.07.0243.

29. Ejaz A, Spolverato G, Kim Y, Poultsides GA, Fields RC, Bloomston M, Cho CS, Votanopoulos K, Maithel SK, Pawlik TM. Impact of body mass index on perioperative outcomes and survival after resection for gastric cancer. J Surg Res. 2015;195(1):74-82. https://doi.org/10.1016/j.jss.2014.12.048.

30. Deng J, Liang H, Sun D, Wang D, Pan Y. Suitability of 7th UICC N category for predicting the overall survival of gastric cancer patients after curative resection in China. Ann Surg Oncol. 2010;17(5):1259-66. https://doi.org/ 10.1245/s10434-010-0939-x.

31. Chae S, Lee A, Lee JH. The effectiveness of the new (7th) UICC N classification in the prognosis evaluation of gastric cancer patients: a comparative study between the 5th/6th and 7th UICC N classification. Gastric Cancer. 2011;14(2):166-71. https://doi.org/10.1007/s10120-011-0024-6.

32. Mita K, Ito H, Fukumoto M, Murabayashi R, Koizumi K, Hayashi T, Kikuchi $\mathrm{H}$. Surgical outcomes and survival after extended multiorgan resection for T4 gastric cancer. Am J Surg. 2012;203(1):107-11. https://doi.org/10. 1016/j.amjsurg.2010.12.007.

33. Siewert JR, Bottcher K, Stein HJ, Roder JD. Relevant prognostic factors in gastric cancer: ten-year results of the German Gastric Cancer Study. Ann Surg. 1998;228(4):449-61.

34. Kim JP, Kim YW, Yang HK, Noh DY. Significant prognostic factors by multivariate analysis of 3926 gastric cancer patients. World J Surg. 1994;18(6):872-7 (discussion 877-878).

35. Chen XL, Zhao LY, Xue L, Xu YH, Zhang WH, Liu K, Chen XZ, Yang K, Zhang B, Chen ZX, Chen JP, Zhou ZG, Hu JK. Prognostic significance and the role in TNM category of extranodal metastasis within regional lymph nodes station in gastric carcinoma. Oncotarget. 2016;7(41):67047-60. https:// doi.org/10.18632/oncotarget.11478.

36. Ozer I, Bostanci EB, Orug T, Ozogul YB, Ulas M, Ercan M, Kece C, Atalay F, Akoglu M. Surgical outcomes and survival after multiorgan resection for locally advanced gastric cancer. Am J Surg. 2009;198(1):25-30. https://doi. org/10.1016/j.amjsurg.2008.06.031.

37. Cheng CT, Tsai CY, Hsu JT, Vinayak R, Liu KH, Yeh CN, Yeh TS, Hwang TL, Jan YY. Aggressive surgical approach for patients with T4 gastric carcinoma: promise or myth? Ann Surg Oncol. 2011;18(6):1606-14. https://doi.org/ 10.1245/s10434-010-1534-x.

38. Dhar DK, Kubota H, Tachibana M, Kinugasa S, Masunaga R, Shibakita M, Kohno H, Nagasue N. Prognosis of T4 gastric carcinoma patients: an appraisal of aggressive surgical treatment. J Surg Oncol. 2001;76(4):278-82.

39. Chiu CF, Yang HR, Yang MD, Jeng LB, Yang TY, Sargeant AM, Bai LY. Palliative gastrectomy prolongs survival of metastatic gastric cancer patients with normal preoperative CEA or CA19-9 values: a retrospective cohort study. Gastroenterol Res Pract. 2016;2016:6846027. https://doi.org/10. 1155/2016/6846027.

40. Deng K, Yang L, Hu B, Wu H, Zhu H, Tang C. The prognostic significance of pretreatment serum CEA levels in gastric cancer: a meta-analysis including 14651 patients. PLoS ONE. 2015;10(4):e0124151. https://doi.org/10. 1371/journal.pone. 0124151

41. Sakr Y. Alhussami, IImi, Nanchal, Rahul, Being overweight is associated with greater survival in ICU patients: results from the intensive care over nations audit. Crit Care Med. 2015;43(12):2623-32. https://doi.org/10. 1097/CCM.0000000000001310。

42. Mirna B. Marques 1, Lies Langouche, endocrine, metabolic, and morphologic alterations of adipose tissue during critical illness. Crit Care Med. 2013;41(1):317-25. https://doi.org/10.1097/CCM.0b013e318265f21c.

\section{Publisher's Note}

Springer Nature remains neutral with regard to jurisdictional claims in published maps and institutional affiliations. 